\title{
A szaruhártya felszíni hömérséklete és légáramlási viszonyainak alakulása refraktív célú lézeres beavatkozás közben három különböző típusú és ismétlési frekvenciájú excimer lézerberendezésnél
}

\author{
Szekrényesi Csaba ${ }^{1}$ - Sándor Gábor László dr. ${ }^{2}$. Gyenes Andrea dr. ${ }^{2}$ \\ Kiss Huba dr. ${ }^{2}$ - Filkorn Tamás dr., ${ }^{1,2}$ - Nagy Zoltán Zsolt dr. ${ }^{1,2}$ \\ Semmelweis Egyetem, ${ }^{1}$ Egészségtudományi Kar, ${ }^{2}$ Általános Orvostudományi Kar, Szemészeti Klinika, Budapest
}

Bevezetés: A cornea törőerejének excimer lézerrel történő módosítása közben a termikus viszonyok alakulása fontos tényező lehet a sebgyógyulás és a hosszú távú eredmények szempontjából. Célkituzés: A tanulmány célja a refraktív mútét során a szaruhártya felszíni hőmérsékletének vizsgálata három különböző lézerplatformnál Módszer: A vizsgálatot 90 beteg egyik kezelt szemén végezték, amelyeken Carl Zeiss MEL 70 és MEL 80, illetve Wavelight Allegretto típusú lézerrel történt photorefractiv keratectomia kezelés. EBRO TLC 730 infravörös hőmérővel végeztek mérést közvetlenül a hámeltávolítás előtt, valamint közvetlenül a kezelés előtt és után. A betegek átlagéletkora 25,5 \pm év volt. Minden fénytörési hiba myopiás vagy myop astigmiás volt, átlaguk $-3,2 \pm 0,8$ Dpt volt. Eredmények: A felszíni cornea hőmérsékletének alakulásában statisztikailag szignifikáns különbség volt a MEL 80 és a másik két típusú lézer között. Következtetések: A lézerkészülékek szöveti gőzök eltávolítására szolgáló elszívórendszere által okozott különböző mértékủ légáramlási viszonyok befolyásolhatják a hőmérsékleti viszonyainak alakulását. Ez a refraktív eredményeket nem befolyásolta. Orv. Hetil., 2016, 157(43), 1717-1721.

Kulcsszavak: refraktív sebészet, PRK, szaruhártya felszíni hőmérséklete, sebgyógyulás

Relationship between corneal surface temperature and air flow conditions during refractive laser eye surgery using three different excimer lasers

\begin{abstract}
Introduction: Thermal conditions during photorefractive keratectomy might be an important issue related to the corneal wound healing and long-term outcomes. Aim: Authors tried to find out the importance of temperature conditions during the treatment. Method: One eye of 90 patients has been included into the study. Photorefractive keratoctomy was applied with Carl Zeiss MEL 70, MEL 80 and Wavelight Allegretto excimer lasers. EBRO TLC 730 infrared thermometer was used for the measurement of surface temperature of the cornea before epithelial removal, as well as before and after the treatment. Average age of the patients was $25.5 \pm 3 \mathrm{yr}$. Average myopic correction was $-3.2 \pm 0.8$ Dpt. Results: Statistically significant difference was found in temperature change between MEL 80 and the other two types of excimer laser devices. Conclusions: Different air flow conditions of the smoke removal system might have an influence on changes of the corneal temperature during treatment, but the refractive results were not influenced by this issue.
\end{abstract}

Keywords: refractive surgery, PRK, corneal surface temperature, wound healing

Szekrényesi, Cs., Sándor, G. L., Gyenes, A., Kiss, H., Filkorn, T., Nagy, Z. Zs. [Relationship between corneal surface temperature and air flow conditions during refractive laser eye surgery using three different excimer lasers]. Orv. Hetil., 2016, 157(43), 1717-1721.

(Beérkezett: 2016. május 21.; elfogadva: 2016. augusztus 10.) 


\section{Rövidítések}

LASEK = laser-assisted sub-epithelial keratectomy; $\mathrm{MMC}=$ mitomycin C; PRK = photorefractive keratectomy; PTK = phototherapeutic keratectomy

A lézeres refraktív eljárás talán a leggyakrabban alkalmazott beavatkozás a szemészetben. Becslések szerint az évszázad végére a Föld lakosságának harmada rövidlátó lesz [1]. A szem törőerejének lézeres korrekciója megbízható, gyors és minimális kényelmetlenséggel járó megoldást kínál számukra. A választható módszerek között felszíni eljárások (PRK, PTK, LASEK), valamint lebenyes megoldások is vannak. Mindkét eljárástípusban folyamatos a fejlődés, a gyártók gyorsaságban, pontosságban, technológiai tudásban és megbízhatóságban is évről évre tökéletesítik készülékeiket [2-5].

A korai idők óta az elektromágneses spektrum UVtartományának 193 nm-es hullámhosszúságú impulzusait használjuk a szaruhártya formájának alakítására, amelyet argon-fluorid gázzal múködő excimer lézerrel hozunk létre. A lézerimpulzus a felszínre érve photoablatiót okoz, a sugárzás energiája a kémiai kötések felbomlásához vezet, amely kismértékű hőfejlődéssel jár. A szaruhártya sebgyógyulására, a kialakuló metabolikus folyamatokra, a szaruhártyahomályokra (haze-re) és a hosszú távú eredményekre a korábbi tanulmányok szerint az optikai zóna, a sebész tapasztalata, a kezelési idő, a kezelt dioptria tartománya, a lézersugár paraméterei, frekvenciája, átmérője, energiasűrüsége, valamint a beavatkozás közbeni környező termikus viszonyok is hatással lehetnek $[6,7]$.

A korábbi kutatások alapján a felszíni hőmérséklet emelkedése a lézerberendezéstől és a mérési technikától függően 4 és $96{ }^{\circ} \mathrm{C}$ között alakulhat [8]. Az alkalmazott mérési technikák az infravörös tartományú sugárzásméréstől a hőkamerás megoldásokig, az időbeli felbontás a másodpercestől a mikromásodpercesig terjednek.

Ebben a tanulmányban a szaruhártya hőmérsékletének változását vizsgáltuk három különböző excimer lézerberendezés esetén, amelyek egy $35 \mathrm{~Hz}$ ismétlési frekvenciájú MEL 70 (Carl Zeiss Meditec GmbH, Jéna, Németország), egy $250 \mathrm{~Hz}$ ismétlési frekvenciájú MEL 80 (Carl Zeiss Meditec GmbH, Jéna, Németország), valamint egy $400 \mathrm{~Hz}$ ismétlési frekvenciájú Wavelight Allegretto (Wavelight Inc., Erlangen, Németország).

Mindhárom lézerplatform repülőpont-technológiát használ a szaruhártya hőterhelésének csökkentésére és egyenletesebbé tételére. A keletkező szöveti gőzök eltávolítására mindegyik berendezés szűrővel ellátott külön elszívórendszerrel rendelkezik. A kezelés közben a szaruhártya felszínén áramló levegő eltávolítja az ablált szöveti maradékokat az újabb lézerimpulzusok útjából és egyúttal húti is a felszínt. A lézerimpulzus útjában maradó el nem távolított gőzökben az impulzus energiája el- nyelődhetne, amely nem kívánt ablatiós hatáscsökkenést eredményezhet.

A szaruhártya felszínéről az ablatiókor megjelenő hőmennyiség a környezet felé hősugárzással és kondukcióval, a szem belseje felé kondukcióval és konvekcióval adódik át [9, 10]. A légáramlás sebessége ezért a hütőhatást is befolyásolhatja, így a vizsgálat tárgyát képezte a felszíni légáramlási viszonyok megmérése.

\section{Módszer}

A 90 páciens (37 férfi és 53 nő) egyik szemének eredményei a kezeléshez használt lézerberendezés alapján három azonos nagyságú csoportba oszthatók. A páciensek átlagéletkora 25,5 \pm 3 év. Minden kezelt dioptria myopiás vagy myop astigmiás volt, szférikus ekvivalensük átlaga $-3,2 \pm 0,8$ Dpt. A preoperatív szférikus törőerő minimum $-2,5 \mathrm{Dpt}$, maximum $-6,5 \mathrm{Dpt}$, a maximális astigmia $-1,25$ cyl Dpt volt. A kezelési átmérő minden esetben $6,5 \mathrm{~mm}$ volt. A posztoperatív UV-expozíció hatásának kizárására a kezelések késő ősszel történtek. Minden páciensnél ez volt az első refraktív sebészeti beavatkozás. Kaukázusi nagy rasszból származó fehér bőrü páciensek kerültek kiválasztásra [11].

\section{Csoportok}

1. csoport: MEL 70 excimer lézer (Carl Zeiss Meditec GmbH, Jéna, Németország) n = 30 szem (11 férfi, 19 nő; átlagéletkor $25,8 \pm 2,8$ év).

2. csoport: MEL 80 excimer lézer (Carl Zeiss Meditec GmbH, Jéna, Németország) n = 30 szem (16 férfi, 14 nő; átlagéletkor 25,5 $\pm 2,5$ év).

3. csoport: Allegretto excimer lézer (Wavelight Inc., Erlangen, Németország) n = 30 szem (10 férfi, 20 nő; átlagéletkor $25,3 \pm 3,8$ év).

A csoportok preoperatív jellemzői az 1. táblázatban kerültek rögzítésre. A csoportok más paramétereikben nem különböztek statisztikailag.

A hőmérsékletmérés tizedfokos mérési pontosságú infravörös sugárzásmérés elvű, kalibrált hőmérővel (EBRO TLC 730, WTW GmbH, Németország) történt. A hőmérő infravörös mérési zónájának mérete $(S)$ a távolsággal nő $(\mathrm{D})$, ezek arányát a $\mathrm{D} / \mathrm{S}=8 / 1$ képlet írja le. A $8 \mathrm{~cm}$ távolságból végzett mérés bemért zónájának átmérője $1 \mathrm{~cm}$, amellyel a kezelt terület lokalizációja a készülék saját látható vörös tartományú lézerdiódái segítségével nagy pontossággal tartható volt. Az azonnali, gombnyomásra történő mérés a kezelés menetét és eredményét nem befolyásolta.

A kezelés előtt minden pácienst megvizsgáltunk autorefraktométerrel, korrekció nélküli közeli és távoli látásélesség-vizsgálattal, korrekcióval együtt mind normál, mind tágított pupillával, szaruhártya-topográffal, szaruhártyavastagság-méréssel és Pentacam Scheimpflug vizsgálattal. 
A páciensek háromszor kaptak kezelés előtt közvetlenül oxibuprocaine hydrochloride érzéstelenítést. A szaruhártya felszínének hőmérsékletét mértük hámeltávolítás előtt, majd közvetlenül kezelés előtt és után azonnal. A páciens ez után 30 másodperces $0,02 \%$-os töménységú MMC-t, végül 15 másodpercen át tartó hideg $\left(+4{ }^{\circ} \mathrm{C}\right)$ fiziológiás sóoldatos öblítést kapott. A kezelési idők hossza 7 s-tól 90 s-ig alakult. A kezelés végén a szaruhártyára lágy kontaktlencsét helyeztünk, végül tobramycincseppet cseppentettünk a felszínre. A kezelt páciensek a posztoperatív időszakban prevencióként naponta $5 \times 1$ fluorometholoncseppet kaptak, havonta csökkentve.

A lézerberendezések elszívóegysége a szaruhártya felszínén, a munkamagasságban közel lamináris áramlást hoz létre az ablatiókor felszabaduló szöveti gőzök eltávolítására. Az áramlás mérésekor a mütéti elrendezést és légáramlási viszonyokat átlagos emberi fej nagyságú és alakú szivacspárnával szimuláltuk. Az áramlásmérés nagy pontosságú, anemométer-elvű áramlásmérővel (TESTO 405-Vl) (TESTO GmbH, Lenzkirch, Németország) (pontosság: $0-2 \mathrm{~m} / \mathrm{s}-i g \pm[0,1 \mathrm{~m} / \mathrm{s} \pm$ vagy a mért érték $\pm 5 \%$-a]; 2,1 -tól $10 \mathrm{~m} / \mathrm{s}$-ig $\pm[0,3 \mathrm{~m} / \mathrm{s}$ vagy a mért érték $\pm 5 \%$-a]) történt.

A kezelőhelyiség hőmérséklete és páratartalma szabályozott volt, a készülékek által kibocsátott hő mellett a hőmérséklet $22 \pm 1{ }^{\circ} \mathrm{C}$-on, a páratartalom $35 \pm 5 \%$-on belül maradt [12]. A készülékek által kibocsátott hő a mérési eredményeket nem befolyásolta.

A mért hőmérséklet-változásokat az ablatiós mélységtől függően úgy elemeztük, hogy kizártuk a különböző nagyságú kezelési mélységek és idők hatását, majd egy szempontú ANOVA-analízisnek vetettük alá.

\section{Eredmények}

A lézerkészülékek gyári beállításaival a Carl Zeiss MEL 70 lézernél a munkafelszínen mért áramlási sebesség 0,4 $\mathrm{m} / \mathrm{s}$ volt. A Carl Zeiss MEL 80-nál ugyanez 2,2 m/s, a Wavelight Allegrettónál pedig $0,15 \mathrm{~m} / \mathrm{s}$ volt.

A hőmérsékletmérési eredmények alakulása grafikusan megjelenítve látható az 1 ábrán. A mérési pontok magyarázata: hámeltávolítás előtt közvetlenül (1.), kezelés előtt közvetlenül (2.) és kezelés után közvetlenül (3.) (1. ábra).

A MEL 80 lézerrel történt kezeléskor a hőmérsékletcsökkenés kifejezettebb volt a másik két lézerhez képest. A MEL 80-nal a kezelés alatt a hőmérséklet 2,3 $00,8^{\circ} \mathrm{C}$ ot, a MEL 70 -nel $0,3 \pm 0,5{ }^{\circ} \mathrm{C}$-ot, az Allegrettóval $0,5 \pm 0,4{ }^{\circ} \mathrm{C}$-ot csökkent.

$\mathrm{Az}$ egyes kezelések alatt mért hőmérséklet-csökkenést a kezelési mélységgel osztva kezelésenként ${ }^{\circ} \mathrm{C} / \mu \mathrm{m}$ dimenziójú viszonyszámot kaptunk, amely kifejezi az egységnyi kezelési mélységre eső hőmérséklet-változást. Ezek átlagát pácienscsoportonként véve az adott lézernél a hőmérséklet-változásra jellemző értékeket kaptunk, amelyek így az ablált szövet mennyiségétől nem függenek, csak a lézer paramétereitől.

$\mathrm{Az}$ így kapott átlagolt viszonyszámok szórással együtt a MEL 80 lézernél $-4,8 \pm 1,6{ }^{\circ} \mathrm{C} / 100 \mu \mathrm{m}$, a MEL 70nél $-1,0 \pm 1,8^{\circ} \mathrm{C} / 100 \mu \mathrm{m}$, az Allegrettónál $-1,1 \pm 1,1$ ${ }^{\circ} \mathrm{C} / 100 \mu \mathrm{m}$. Azaz egységnyi ablatióra vetítve a MEL 80nál mérhető hőmérséklet-változás jelentősen nagyobb.

Ezeket az eredményeket egy szempontú ANOVA-varianciaanalízissel vizsgálva statisztikailag szignifikáns különbséget találtunk a hőmérséklet alakulása és a lézerek

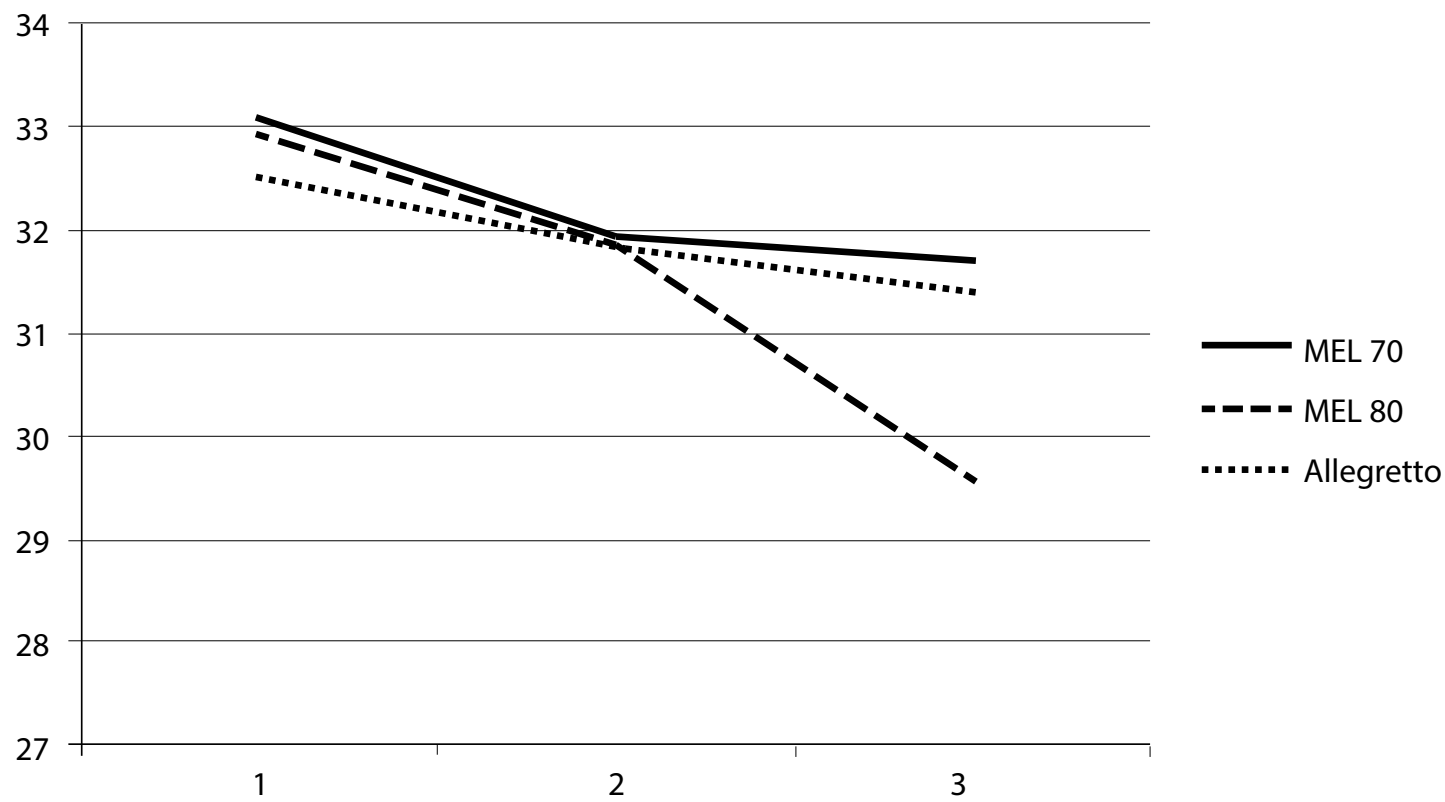

\begin{tabular}{l|l} 
1. ábra & A hőmérsékletmérési eredmények alakulása \\
A mérési pontok magyarázata: 1. hámeltávolítás eloott közvetlenül, 2. kezelés előtt közvetlenül, 3. kezelés után közvetlenül
\end{tabular} 
Operáció előtti és utáni törőerő, látásélesség, ablatiós mélység, haze és szubjektív fájdalom skála a vizsgált csoportokban

\begin{tabular}{|c|c|c|c|}
\hline & MEL 70 & MEL 80 & Allegretto \\
\hline Operáció előtti átlagos refrakció & $-3,2 \pm 1,1 \mathrm{Dpt}$ & $-3,4 \pm 0,7 \mathrm{Dpt}$ & $-3,1 \pm 0,7 \mathrm{Dpt}$ \\
\hline Operáció előtti korrigálatlan látásélesség & 0,15 & 0,1 & 0,1 \\
\hline Operáció előtti legjobb korrigált látásélesség & 1 & 1 & 1 \\
\hline Ablatiós mélység & $42 \pm 16 \mu \mathrm{m}$ & $48 \pm 8 \mu \mathrm{m}$ & $46 \pm 12 \mu \mathrm{m}$ \\
\hline Operáció utáni átlagos refrakció (6 hónapos) & $-0,04 \pm 0,3 \mathrm{Dpt}$ & $-0,08 \pm 0,4 \mathrm{Dpt}$ & $-0,07 \pm 0,4 \mathrm{Dpt}$ \\
\hline Operáció utáni korrigálatlan látásélesség & 0,92 & 0,93 & 0,93 \\
\hline Operáció utáni legjobb korrigált látásélesség & 1 & 1 & 1 \\
\hline Operáció utáni haze ( 1 hónapos) & 0,25 & 0,22 & 0,23 \\
\hline Operáció utáni haze (3 hónapos) & 0,2 & 0,2 & 0,19 \\
\hline Operáció utáni haze (6 hónapos) & 0,11 & 0,15 & 0,14 \\
\hline Szubjektív fájdalom skála (1 napos) & $1,97 \pm 0,76$ & $1,87 \pm 0,78$ & $1,93 \pm 0,74$ \\
\hline Szubjektív fájdalom skála (3 napos) & $1,43 \pm 0,62$ & $1,5 \pm 0,68$ & $1,47 \pm 0,62$ \\
\hline
\end{tabular}

között. A post-hoc Bonferini-teszttel statisztikailag szignifikáns különbséget találtunk a MEL 80 és a másik két lézer között, p<0,05. A MEL 70 és Allegretto lézerek között nem volt ilyen különbség.

A csoportok között az operáció előtti átlagos refrakció értékében és a 6. hónapos operáció utáni átlagos refrakció értékében nem volt szignifikáns különbség.

Hanna és mtsai szerint meghatároztuk a mútét utáni subepithelialis homály (haze) átlagos értékét. Sem az 1 hónapos, sem a 3 hónapos, sem a 6 hónapos értékekben, sem pedig az 1 és 3 napos 5 pontos szubjektív fájdalom skálán nem volt szignifikáns különbség a vizsgált csoportok között (1. táblázat).

\section{Megbeszélés}

Korábbi tanulmányok megmutatták, hogy a PRK-kezelés közbeni maximális hőmérséklet-emelkedés korai lézereknél akár $7,5{ }^{\circ} \mathrm{C}$ is lehet $[13,14]$. Pozitív korrelációt találtak az ablatio mélysége és a cornea felszíni hőmérsékletének változása között [15]. Más tanulmányok azt mutatták be, hogy közvetlenül a PRK-kezelés után a cornea hütése csökkenti a subepithelialis haze kockázatát $[16,17]$.

A felszín hőmérsékleti előkészítése szintén előnyösen hathat a cornealis sebgyógyulásra. A hősokkfehérjék a hưtés vagy a melegítés révén a gyógyulás kimenetelében fontos szerepet játszhatnak [18]. Más tanulmányok szerint a lézer ismétlési frekvenciája nem bír befolyással a PRK hosszú távú kimenetelére [19]. A repülőpont-technológiával múködő lézerek ablatiós algoritmusok segítségével csökkentik a szaruhártyán mérhető csúcshőmérsékletet [10].

Ebben a tanulmányban azt vizsgáljuk, hogy klinikai körülmények között a cornea felszíni hőmérséklete hogyan változik rögzített környezeti paraméterek és ismert lokális légáramlási viszonyok mellett, valamint, hogy mindez hogyan függ a különböző tulajdonságú lézerplatformoktól.
Szignifikáns különbséget találtunk az ablatiós mélység hatásának kivonása után a Carl Zeiss MEL 80 lézerrel kezelt páciensek szaruhártya-hőmérsékletének alakulásában a MEL 70 és Allegretto lézerplatformhoz viszonyítva. A Carl Zeiss MEL 80 lézer gyári elszívórendszere által létrehozott erőteljesebb áramlás $(2,2 \mathrm{~m} / \mathrm{s}$; szemben a Carl Zeiss MEL $700,4 \mathrm{~m} / \mathrm{s}$-os, valamint a Wavelight Allegretto $0,15 \mathrm{~m} / \mathrm{s}$-os áramlásával) okozta fokozott hütőhatás magyarázhatja ezt a jelenséget. A csoportok kezelés utáni refraktív eredményének és a kialakuló hazenek a hosszú távú követési eredményeinek hasonlósága azonban statisztikailag szignifikáns különbséget nem mutat. Mindez arra utalhat, hogy bár a hütőhatás különböző, amely a szaruhártya felszínének különböző hőmérsékletét okozza, ez a kezelés eredményére és kockázataira (haze) nincs befolyással.

Anyagi támogatás: A szerzők a cikk előkészületeihez, kidolgozásához, megírásához anyagi támogatásban nem részesültek.

Szerzôi munkamegosztás: Sz. Cs., N. Z. Zs.: Hipotézisek kidolgozása. Sz. Cs., N. Z. Zs., S. G. L., Gy. A., K. H., F. G.: A vizsgálat lefolytatása. Sz. Cs., N. Z. Zs.: Statisztikai elemzés. Sz. Cs., N. Z. Zs.: A kézirat megírása. A cikk végső változatát valamennyi szerző elolvasta és jóváhagyta.

Érdekeltségek: A szerzőknek nincsenek érdekeltségeik.

\section{Irodalom}

[1] Dolgin, E.: The myopia boom. Nature, 2015, 519(7543), 276278.

[2] Müller, B., Boeck, T., Hartmann, C.: Effect of excimer laser beam delivery and beam shaping on corneal sphericity in photorefractive keratectomy. J. Cataract Refract. Surg., 2004, 30(2), 464470.

[3] Fiore, T., Carones, F., Brancato, R.: Broad beam vs. flying spot excimer laser: refractive and videokeratographic outcomes of two 
different ablation profiles after photorefractive keratectomy. J. Refract. Surg., 2001, 17(5), 534-541.

[4] Pettit, G. H.: The ideal excimer beam for refractive surgery. J. Refract. Surg., 2006, 22(9), S969-S972.

[5] Khoramnia, R., Lohmann, C. P., Wuellner, C., et al.: Effect of 3 excimer laser ablation frequencies $(200 \mathrm{~Hz}, 500 \mathrm{~Hz}, 1000 \mathrm{~Hz})$ on the cornea using a $1000 \mathrm{~Hz}$ scanning-spot excimer laser. J. Cataract Refract. Surg., 2010, 36(8), 1385-1391.

[6] Kwon, ., Bott, S.: Postsurgery corneal asphericity and spherical aberration due to ablation efficiency reduction and corneal remodelling in refractive surgeries. Eye (Lond.). 2009, 23(9), $1845-1850$

[7] Lackerbaner, C. A., Grüterich, M., Ulbig, M., et al.: Correlation between estimated and measured corneal ablation and refractive outcomes in laser in situ keratomileusis for myopia. J. Cataract Refract. Surg., 2009, 35(8), 1343-1347.

[8] Ishibara, M., Arai, T., Sato, S., et al.: Measurement of the surface temperature of the cornea during ArF excimer laser ablation by thermal radiometry with a 15 -nanosecond time response. Lasers Surg. Med., 2002, 30(1), 54-59.

[9] Efron, N., Young, G., Brennan, N. A.: Ocular surface temperature. Curr. Eye Res., 1989, 8(9), 901-906.

[10] De Ortueta, D., Magnago, T., Triefenbach, N., et al.: In vivo measurements of thermal load during ablation in high-speed laser corneal refractive surgery. J. Refract. Surg., 2012, 28(1), 53-58.

[11] Tabbara, K. F., El-Sheikh, H. F., Sharara, N. A., et al.: Corneal haze among blue eyes and brown eyes after photorefractive keratectomy. Ophthalmology, 1999, 106(11), 2210-2215.
[12] Dantas, P. E., Martins, C. L., de Souza, L. B., et al.: Do environmental factors influence excimer laser pulse fluence and efficacy? J. Refract. Surg., 2007, 23(3), 307-309.

[13] Bende, T., Seiler, T., Wollansak, J.: Side effects in excimer corneal surgery. Corneal thermal gradients. Graefes Arch. Clin. Exp. Ophthalmol., 1988, 226(3), 277-280.

[14] Langenbucher, A., Seitz, B., Kus, M. M., et al.: Thermal effects in excimer laser trephination of the cornea. Graefes Arch. Clin. Exp. Ophthalmol., 1996, 234(Suppl. 1), S142-S148.

[15] Maldonado-Codina, C., Morgan, P. B., Efron, N.: Thermal consequences of photorefractive keratectomy. Cornea, 2001, 20(5), 509-515.

[16] Tsubota, K., Toda, I., Itoh, S.: Reduction of subepithelial haze after photorefractive keratectomy by cooling the cornea. Am. J. Ophthalmol., 1993, 115(6), 820-821.

[17] Park, W. C., Tseng, S. C.: Temperature cooling reduces keratocyte death in excimer laser ablated corneal and skin wounds. Invest Ophthalmol. Vis. Sci., 1998, 39(Suppl.), S449.

[18] Kim, J. M., Kim, J. C., Park, W. C., et al.: Effect of thermal preconditioning before excimer laser photoablation. J. Korean Med. Sci., 2004, 19(3), 437-446.

[19] Kymionis, G. D., Diakonis, V. F., Kounis, G., et al.: Effect of excimer laser repetition rate on outcomes after photorefractive keratectomy. J. Cataract Refract. Surg., 2008, 34(6), 916-919.

(Szekrényesi Csaba, Budapest, Vas utca 17., 1088 e-mail: szekrenyesi@gmail.com)

\section{Tisztelt Szerzőink, Olvasóink!}

Az Orvosi Hetilapban megjelenő/megjelent közlemények elérhetőségére több lehetőség kínálkozik.

Rendelhetö különlenyomat, melynek áráról bővebben a www.akkrt.hu honlapon (Folyóirat Szerzőknek, Különlenyomat menüpont alatt) vagy Szerkesztöségünkben tájékozódhatnak.

A közlemények megvásárolhatók pdf-formátumban is, illetve igényelhető Optional Open Article (www.oopenart.com).

Adott dij ellenében az online közlemények bárki számára hozzáférhetök honlapunkon (a közlemények külön linket kapnak, igy más oldalról is linkelhetővé válnak).

Bővebb információ a hirdetes@akkrt.hu címen vagy különlenyomat rendelése esetén a Szerkesztőségtől kérhető. 